\title{
The reciprocal interaction between degradation of glucose and ecosystem structure. Studies in mixed chemostat cultures of marine bacteria, algae, and bacterivorous nanoflagellates
}

\author{
Bente Pengerud*, Evy F. Skjoldal \& T. Frede Thingstad**
}

Department of Microbiology and Plant Physiology, University of Bergen, Allégt. 70, 5000 Bergen, Norway

\begin{abstract}
The reciprocal interaction between bacterial degradation of glucose and trophic interactions within the microbial ecosystem was studied in mixed cultures with different combinations of the bacterium Pseudomonas putida, the diatom Skeletonema costatum, and a marine bacterivorous nanoflagellate. For each combination of organisms, 8 parallel chemostats were arranged along a gradient of increasing glucose concentration in the reservoirs. Glucose and/or or thophosphate were the limiting nutrients. In cultures with bacteria alone, exhaustion of the medium for both glucose and phosphate was observed for an extended range of reservoir C: P ratios, in a sense violating 'Liebigs law of the minimum'. In cultures with bacteria and flagellates, glucose degradation was stimulated relative to the cultures with bacteria alone, an effect attributed to phosphate remineralization. In these cultures, an increase in reservoir glucose concentration led to increased numbers of bacterial predators, not to increased numbers of bacteria. In cultures with bacteria and algae, the bacteria outcompeted algae for phosphate, and algae disappeared from the cultures at high reservoir $C:$ P ratios. In mixed cultures with all 3 trophic levels bacterial degradation of glucose was strongly impeded relative to all the other situations with bacteria present. Consequently, only a mininor effect of glucose degradation on ecosystem composition could be discerned. In these 3-species communities, algae maintained themselves in the cultures at all reservoir glucose concentrations. These effects were attributed to the combined pressure of predation and competition on the bacteria, and could not be explained by any of these mechanisms individually. Major features of the system could be explained using relatively simple mathematical models previously published.
\end{abstract}

\section{INTRODUCTION}

In their discussion of the implications of the interactions between the trophic levels of the pelagic microbial ecosystem, Azam et al. (1983) pointed out how transformations of organic material in this system must be linked to the processes of mineral nutrient cycling and the multitude of ecological interactions taking place between bacteria, algae and their predators. Processes such as the commensalism between algae and bacteria due to algal excretion of organic matter, the competition between algae and bacteria for mineral nutrients, and the predation on bacteria combined

\footnotetext{
- Present address: A/S Norske Shell, N-4056 Tananger Norway

- Author for correspondence
}

with recycling of mineral nutrients, were pointed to as important in this respect. Knowledge of these foodweb interactions seems necessary for an understanding not only of the functioning of the natural, undisturbed microbial ecosystem, but also for an understanding of the fate and effect of many marine pollutants.

Laboratory ecosystems modelling a variety of interactions have been constructed using pure or mixed cultures of organisms from various trophic levels. Jost et al. $(1973 a$, b) studied a system with competition between bacteria, and predation on these by a ciliate in chemostat cultures. Goldman et al. (1985), Caron et al. (1985), and Andersen et al. (1986) have studied carbon, nitrogen and phosphorus cycling in batch cultures with algae, bacteria and heterotrophic flagellates, while Güde (1985) has studied 
phosphate competition and regeneration between the same trophic levels in a 2-stage chemostat system. Competition has been studied between heterotrophic bacteria (Harder \& Veldkamp 1971, Kuenen et al. 1977), between chemoautotrophic bacteria (Kuenen et al. 1977), between heterotrophic, chemoautotrophic and mixotrophic bacteria (Gottschal et al. 1979, Gottschal \& Thingstad 1982), between photosynthetic bacteria (van Gemerden 1974), between algae (Tilman et al. 1982 and references therein), and between algae and bacteria (Rhee 1972). Mixed competition/inhibition interactions in bacterial cultures have been studied by de Freitas \& Fredrickson (1978), while the mixed competition/commensal relationship between algae and bacteria has been studied in chemostats by Currie \& Kalff (1984) and Bratbak \& Thingstad (1985). Brown et al. (1981) studied the effect of adding organic material to an algae/yeast-community in chemostats. The fate and effects of an externally added carbon source to chemostats with a bacteria/algae/bacterial predator system have been further analyzed by Thingstad \& Pengerud (1985). The work presented here discusses the results obtained with experimental model systems analogous to the mathematical models previously analyzed by Thingstad \& Pengerud (1985).

\section{MATERIALS AND METHODS}

Organisms. To minimize the probability of selecting organisms having evolved specific mutualistic or antagonistic properties through prolonged coexistence, bacteria, algae and bacterivorous flagellates were obtained from different sources.

The bacterium was a marine strain of Pseudomonas putida (NCMB 1960), obtained from the National Collection of Marine Bacteria, Aberdeen. The algae, Skeletonema costatum, originally isolated from the Oslo fjord, was obtained from the culture collection at the Dept. of Marine Botany, University of Oslo, by courtesy of Dr. Svein Kristiansen. The nanoflagellate was isolated using a 2-stage chemostat kept in darkness. The first stage contained a pure culture of $P$. putida, the second stage was inoculated with natural seawater from the Barents Sea. After an initial phase of choanoflagellate dominance, a Monas sp. became dominant and was purified to a uniflagellate culture with $P$, putida as the only bacterium using serial transfers on cultures of $P$. putida grown to stationary phase on the medium used for Chemostat 5 (see below). This medium has a balanced addition of glucose and phosphate and should minimize the possibility for growth of bacterial contaminants during growth of the flagellate. The absence of other bacteria was verified using 'fingerprinting' on agar plates with Oxoid anti- biotic discs of 11 different antibiotics. The radii of the inhibition zones around the disks gave a 'fingerprint' pattern and transfers were continued until the pattern conformed to that of pure P. putida cultures. Antibiotics inhibiting the growth of contaminants were added to the medium during serial transfer. The same fingerprint' system was used to verify the absence of bacterial contaminants during chemostat experiments.

Flagellate predation on the algae was not observed.

Chemostat system. A schematic drawing of the chemostats used is shown in Fig. 1. Of particular

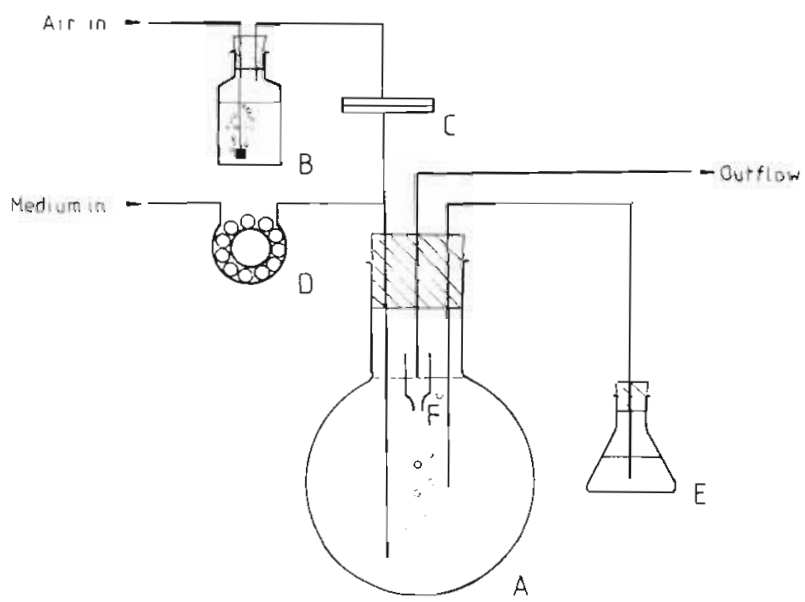

Fig. 1. Chemostat construction. A: culture vessel; B: air moistening unit; $C$ : air sterilizing filter $(0.2 \mu \mathrm{m})$; $D$ : peristaltic pump; E: sample outlet, stored in $70 \%$ ethanol; F: collar surrounding outlet to avoid selective outflow from the outer air/water interface potentially enriched in organisms due to bubble transport

details, a 'collar' made of glass tubing was used on the outlets to avoid overflow being collected from the outer air/water-interface potentially enriched in organisms by bubble transport. Teflon or silicon tubing was used for transporting medium and air into the culture, both matenals sufficiently hydrophobic to avoid the formation of a continuous, wet, surface film. An 8-channel Gilson peristaltic pump was used for media pumping. Culture volumes were $110 \mathrm{ml}$ and dilution rate $0.03 \mathrm{~h}^{-1}$ Temperature was kept at $18^{\circ} \mathrm{C}$. Illumination was continuous with 4 fluorescent tubes (Phillips TL F $65 \mathrm{~W} / 33$ ) giving $330 \mu \mathrm{E} \mathrm{m}^{-2} \mathrm{~s}^{-1}$ at the outside of the cultures. Light was measured using a light meter with spherical sensor (QSL-100, Biospherical Instruments).

Media. All media were based on natural seawater, aged, boiled, and filtered before autoclaving. To the reservoirs of all chemostats were added sterile aqueous solutions of $\mathrm{K}_{2} \mathrm{HPO}_{4}, \mathrm{Na}_{2} \mathrm{NO}_{3}$, and $\mathrm{Na}_{2} \mathrm{SiO}_{3}$ to final concentrations of $10 \mu \mathrm{g}$-at $\mathrm{P} \mathrm{l}^{-1}, 200 \mu \mathrm{g}$-at $\mathrm{N} \mathrm{l}^{-1}$, and $100 \mu \mathrm{g}$-at Si $\mathrm{l}^{-1}$, respectively. Glucose was added to final concentrations of $168,336,834,1668,2502,3336$, 
5004, and $6720 \mu \mathrm{M}$ glucose-C $1^{-1}$ in parallel chemostats numbered 1 through 8 , respectively. Vitamins (Guillard \& Ryther 1962) and trace metals (Eppley et al. 1967) were added. The solid medium used for 'fingerprinting' of bacteria consisted of seawater with $15 \%$ agar, $0.5 \%$ Peptone, $0.5 \%$ Trypton, and $0.5 \%$ Yeast Extract (Difco Bacto).

Measurements. Glucose was measured spectrophotometrically using a commercial peroxidase reagent (Glox, KabiVitrum). Orthophosphate was measured according to Grasshoff et al. (1983), using $1 \mathrm{~cm}$ kuvettes. A Shimadzu UV-120-01 spectrophotometer was used for both analyses.

Bacteria were counted at $1000 \times$ magnification in a Thoma counting chamber; flagellates and algae were counted at $100 \times$ magnification in a Bürker chamber, using a Leitz Orthoplane microscope with phase contrast. All counts were made directly on live samples.

\section{RESULTS}

\section{Bacteria alone}

After an initial transient period of oscillations in bacterial numbers, a steady state was reached in the Pseudomonas putida cultures. The equilibria for 2 different sets of experiments are shown in Fig. 2.

Along the gradient of increasing reservoir glucose concentration, there was an initial linear increase in bacterial density, accompanied by a linear decrease in the concentration of free orthophosphate. The slopes of these lines correspond to a constant yield of $1.6 \times 10^{13}$ cells (mole glucose-C) $)^{-1}$ and a constant molar C:P ratio in bacterial consumption of 140 . For reservoir $C: P$ ratios above approximately 250 , there was no or only slight further increase in bacterial cell density. For reservoir C:P ratios between 140 and approximately 300 , both orthophosphate and glucose were completely consumed. For C:P ratios above approximately 300, additional glucose was not consumed and was found in the cultures as free glucose.

The existence of a range in reservoir $\mathrm{C}: \mathrm{P}$ ratios for which the medium is depleted of both glucose and orthophosphate may be explained using an assumption of changing biomass composition (Thingstad \& Pengerud 1985), and/or changing respiration coefficient, as limitation passes gradually from glucose to phosphate.

\section{Bacteria and flagellates}

Mixed bacteria/flagellate cultures also reached a non-oscillating equilibrium, shown in Fig. 3. With the theoretical assumption of flagellate specific growth

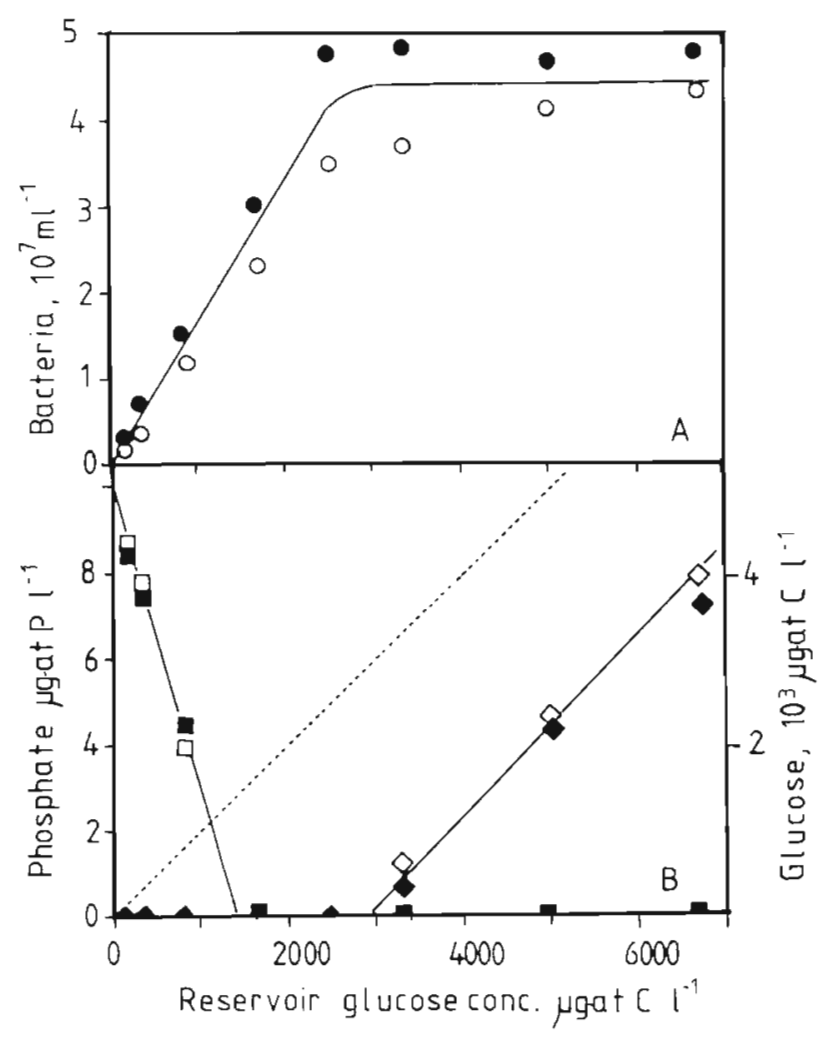

Fig. 2. 'Bacteria alone' cultures. Effect of reservoir glucose concentration on near equilibrium culture concentrations of bacteria $(0, \bullet)$, orthophosphate $(\square, \mathbf{\square})$, and glucose $(\diamond, \bullet)$.Open and closed symbols represent 2 different experiments. Dotted line: culture glucose concentrations in the hypothetical case of no degradation

rate being a function of prey density only, prey density at steady state will be determined by the dilution rate, and not by the reservoir organic nutrient concentration (Thingstad \& Pengerud 1985). In accordance with this, the observed effect of increased reservoir glucose concentration was found to be an increase in flagellate density, not in bacteria. Bacterial density in the cultures became low, about 1 to $2 \times 10^{5} \mathrm{ml}^{-1}$. Flagellate densities increased linearly up to about $2.0 \times 10^{5} \mathrm{ml}^{-1}$ at reservoir $\mathrm{C}: \mathrm{P}$ ratios of about 320 corresponding to about 225 bacteria consumed per flagellate formed.

Relative to the 'bacteria alone' situation, the upper limit of the range of reservoir $\mathrm{C}$ : $\mathrm{P}$ ratios for which free orthophosphate was observed in the cultures was extended from 140 to about 350 , an effect expected as a consequence of flagellate phosphate remineralization. If the $\mathrm{C}: \mathrm{P}$ ratio of bacterial consumption is the same here as in the 'bacteria alone' situation, this corresponds to an estimated recycling of phosphorus of 1.5 times the amount supplied through the medium. Free glucose in the cultures was now found only at much larger reservoir C: P ratios (>500). 


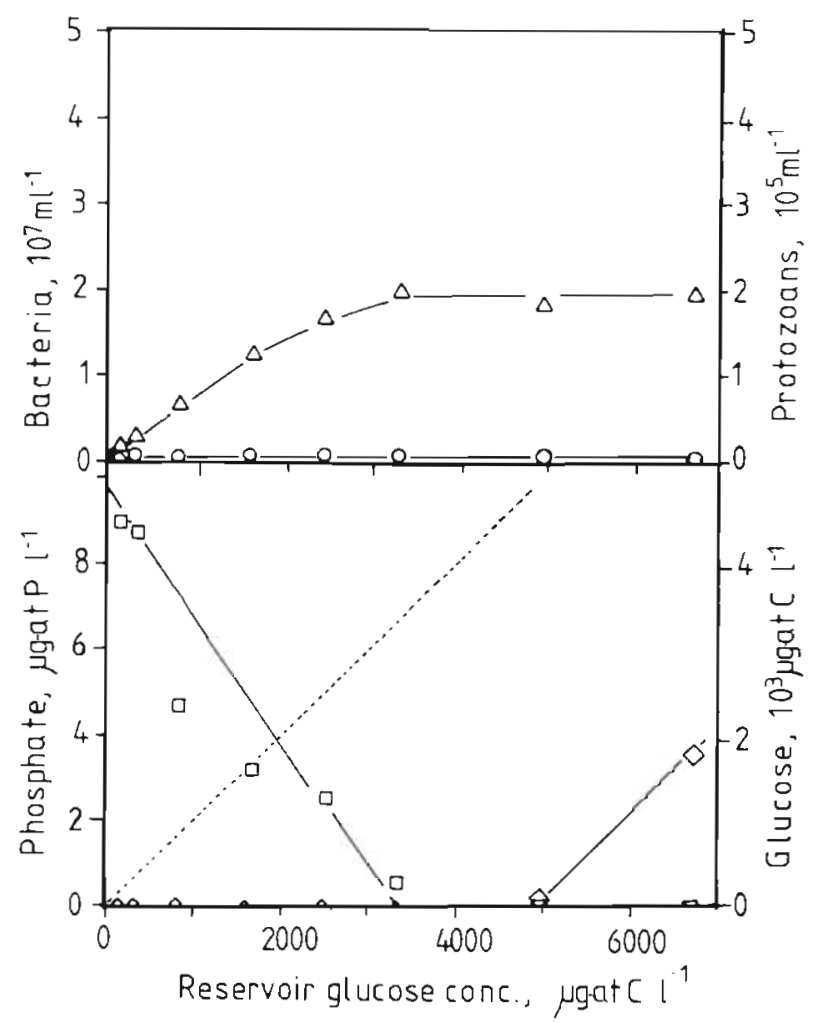

Fig. 3. 'Bacteria and flagellates' cultures. Near-equilibrium culture concentrations of bacteria $(O)$, bacterivorous flagellates $(\Delta)$, orthophosphate $(\square)$, and glucose $(\diamond)$. Dotted line as in Fig. 2

Much higher flagellate densities (data not shown) were found during a transient phase after inoculation of flagellates into established bacterial cultures. Such an overshoot in flagellate density would be the expected effect if flagellates have an important 'maintenance' component (Pirt 1982) in their energy requirement. A comparatively larger fraction of their food supply would then be used for maintenance at the low growth rates forced upon them by the chemostat dilution rate, than would be used when growth is fast on an abundant food supply.

Observed features such as: (1) the increased range of reservour $\mathrm{C}: \mathrm{P}$ ratios for which free orthophosphate was observed; (2) the stimulated glucose degradation; and (3) the increase in bacterial predators, not in bacteria, as a response to increased reservoir glucose concentration, may all be explained using the Monod-formulation of Thingstad \& Pengerud (1985).

\section{Algae alone}

In cultures with algae alone, no effects could be observed of glucose on algal density, nor could any metabolism of glucose by the algae be detected (data not shown). During the initial transient phase, phosphate was depleted when algal density reached about

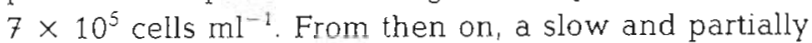
fluctuating increase in algal density followed which could reach densities about $3 \times 10^{\circ}$ cells $\mathrm{ml}^{-1}$. This corresponds to minimum and maximum cell quotas of phosphorus of $0.3 \times 10^{-8}$ and $1.4 \times 10^{-8} \mu \mathrm{g}$-at $\mathrm{P}$ cell $^{-1}$, respectively.

\section{Bacteria and algae}

In cultures with bacteria and algae, 3 sets of experiments with different starting conditions were made (1) inoculation of algae and bacteria at the same time (2) inoculation of algae into established bacterial cultures; and (3) inoculation of bacteria into established algal cultures. No completely stable equilibrium was reached, but the 3 sets of experiments seemed all to approach a situation where Pseudomonas putida outcompeted Skeletonema costatum, giving a near-linear decrease in algal density with increasing reservoir C:P until about 250 (Fig. 4).

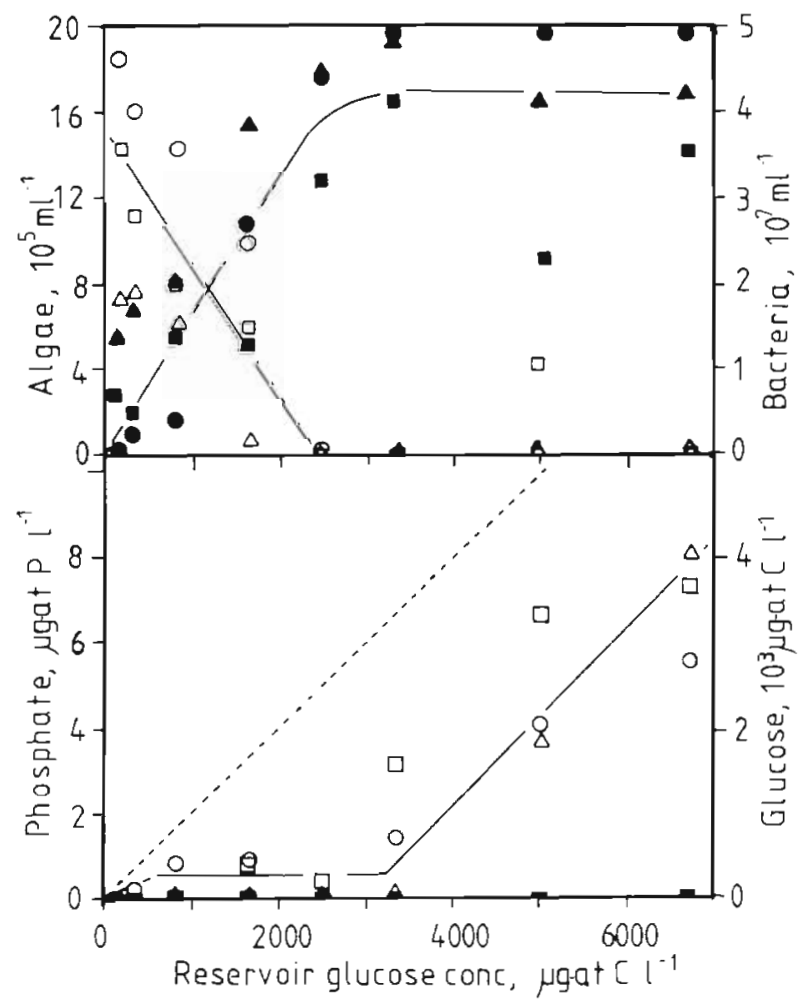

Fig. 4. 'Bacteria and algae' cultures. Near-equilibrium culture concentrations of bacteria (filled symbols, upper frame), algae (open symbols, upper frame), and glucose (open symbols, lower framel. Results of 3 different experiments using different starting conditions: simultaneous inoculation of algae and bacteria $(\square, \boldsymbol{\square})$; bacteria inoculated into established algal cultures $(\Delta, \mathbf{A})$; and algae inoculated into established bacterial cultures $(0, \bullet)$. Orthophosphate ( $\mathbf{\bullet}$ lower frame) was not detectable in any of the cultures. Dotted tine as in Fig. 2 
The algae thus seem to be able to maintain themselves in the chemostats at reservoir $C: P$ ratios higher than 140 , the limit above which no free orthophosphate was present in the bacteria alone situation. This effect was predicted by the Droop model previously analyzed by Thingstad \& Pengerud (1985). A negative effect on glucose degradation in situations with algae present may also be seen as free glucose was detectable in some of the cultures at low reservoir C: P ratios $(<250)$.

The cultures started with inoculation of bacteria into established algal cultures achieved comparatively large bacteria and low algal densities (Fig. 4, triangles). This could be an effect of larger algal exudation of organic substances in these cultures.

\section{Bacteria, algae and flagellates}

In these cultures, algae were able to establish themselves under all reservoir $C: P$ ratios and bacterial degradation of glucose was severely restricted. These effects may be explained by the combined predation/ competition pressure now exerted on the bacteria. A qualitative understanding of this result may be gained by considering that the effect of predation is to keep bacterial density at a low level. At the same time, the algae will bring the equilibrium mineral nutrient concentration in the cultures down to the level where algal specific growth rate equals the dilution rate. Due to a more severe mineral nutrient limitation, specific bacterial growth rate will therefore be less than in the 'bacteria and flagellates' situation. The combination of a low bacterial density and a low bacterial specific growth rate will result in a low total bacterial activity, i.e. in a limited degradation of glucose (Fig. 5). A more detailed mathematical justification of this argument is given in Thingstad \& Pengerud (1985).

As in 'algae alone' cultures, attainment of equilibrium in algal density was slow and fluctuating and no really unequivocal equilibrium in algal density was reached during the experiment. Due to technical problems, Chemostats 2 and 8 had to be shut down and restarted during the equilibration phase, and algal numbers in these were less than in the other 6 chemostats at termination of the experiment (Fig. 5).

\section{DISCUSSION}

The simple mathematical models analyzed by Thingstad \& Pengerud (1985) were found to give realistic predictions of many of the main features observed here in experiments with model ecosystems. In these systems, many aspects of the fate and effect of added organic material thus seem to be explainable by

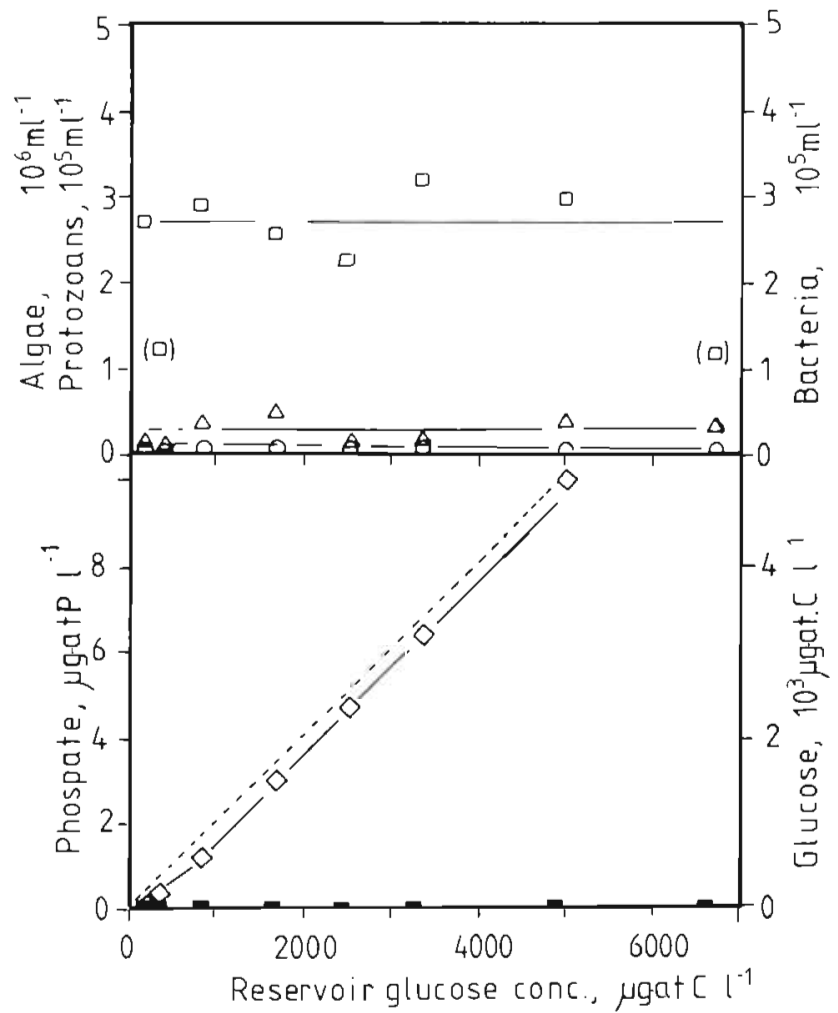

Fig. 5. 'Bacteria, algae, and flagellates' cultures. Near-equilibrium concentrations of bacteria $(0)$, flagellates $(\Delta)$, algae $(\square)$, and glucose $(\diamond)$. Points in parentheses denote algal concentrations in cultures which due to technical problems had shorter equilibration times. Orthophosphate (a) was not detectable in any of the cultures. Dotted line as in Fig. 2

relatively simple interactions such as competition and predation at the ecosystem level, and relatively simple formulations of the physiology at the organism level.

The results demonstrate the care required when interpreting effects in tightly coupled ecosystems as being caused only by mechanisms within one, isolated part of the system: if studied in the 'bacteria, algae, and flagellates' system only, the very limited degradation of glucose shown in Fig. 5 might carelessly have been attributed to the competition between algae and bacteria for phosphorus. As shown, however, competition alone had not nearly the same negative effect on degradation; the bacteria competed successfully with algae for phosphate (Fig. 4). Also, predation alone actually stimulated glucose degradation (Fig. 3). Seen separately, neither of these 2 mechanisms would thus be expected to restrain glucose degradation severely. As seen from Fig. 5, however, the combined effect is a drastic reduction in glucose degradation and hence small effects of glucose degradation on ecosystem biomass distribution.

In natural systems, some indications exist that the enhancement of bacterial competition for mineral nutrients caused by addition of allochthonous organic 
substrates may have a negative effect on primary producers (Parker et al. 1975, Parsons 1981). In our study this was clearly demonstrated in the algae and bacteria' experiment (Fig. 4). In the 'bacteria, algae, and flagellates' experiment, the poorly defined steady states of the algae did not allow a possible negative effect on these to be demonstrated clearly. The existence of a minor negative effect may be inferred, however, since part of the available phosphorus was bound in bacterial and flagellate biomass.

The predatory control of bacterial density, suggested by Fenchel (1982) and Azam et al. (1983), is demonstrated in Fig. 3. Bacterial numbers did not increase with increased organic loading. The tempting conclusion in investigations of natural systems, that high/low bacterial densities correspond to rich/poor bacterial nutrient situations, is therefore at least dangerous. Completely different mechanisms, such as low/high densities of secondary predators preying on the bacterivores, may be equally applicable.

Elaboration of these mathematical and experimental models to include more mechanisms within the microbial complex could alter the conclusions. The predator used here seemed to prey on bacteria only, while protozoans preying on both algae and bacteria are possibly common (Goldman \& Caron 1985).

Photosynthetic organisms with phagotrophic capabilities have recently been suggested to be important in microbial food webs (Porter et al. 1985, Estep et al. 1986). Such mixotrophic organisms would have ecological functions within this system very different from the 'traditional' phototrophs modelled here. This type of predation would not only alter the flow of carbon, even more important would be the potential ability of such organisms to escape the algal-bacterial competition for mineral nutrients. For such mixotrophic organisms, the paradox in algal/bacterial interactions discussed by Bratbak \& Thingstad (1985), would be resolved. Excretion of organic material could in principle facilitate their capture of inorganic nutrients via bacterial biomass. Another possible resolution of the paradox is suggested by the results presented here: if predation pressure on bacteria in the euphotic zone is continuous and severe, algae may not experience mineral nutrient competition from bacteria as a serious problem.

An expansion of the model system, to include higher predatory levels necessary if natural systems are to be analyzed, is also bound to have effects. A larger predator preying on both algae and protozoans would presumably remove some of the competition and also some of the predation pressure on bacteria. Such predators would also stimulate remineralization. The combined effect would be expected to be a stimulation of bacterial degradation of organic material.
Our chemostats were operated under non-fluctuating environmental conditions. Fluctuations in the environment have been shown to have a profound effect on inter-algal competition for mineral nutrients (Sommer 1984, Sakshaug \& Olsen 1986). Whether environmental fluctuations would favor bacterial or algal competition is so far unknown

The complete bacterial removal of both glucose and orthophosphate from the cultures for an extended range of reservoir $C: P$ values shown in Fig. 2 was explained by Thingstad \& Pengerud (1985) using a modified Droop (Droop 1968) formulation of the model for bacterial growth. The phenomenon is interesting since it may seem to violate 'Liebigs law of the minimum'. This possible violation occurs in a steadystate system, and our example is therefore not contained within the qualification given by Odum (1971) that Liebigs law may be violated in non-steady state systems. As shown by Thingstad (1987) the phenomenon may be explained using a model where one substrate only controls growth in cell number, but a number of substrates may control the biomass composition. Whether this should be viewed as a violation of 'Liebigs law', then becomes a question of how 'growth' is defined.

Since a consortium of 'factors', consisting both of multiple chemical resources and multiple ecological interactions, seemed to interact with bacterial growth in our system, a quest for one single controlling factor of bacterial activity would seem rather futile.

Acknowledgements. This work was supported by the Norwegian Research Program for Marine Arctic Ecology (PROMARE). The 'fingerprinting' method for surveillance of bacterial contamination was originally suggested to us by Prof. Ian Dundas, who also provided discussions and critical reading of the manuscript. We also thank Prof. E. Paasche, Univ. of Oslo, for valuable discussions of both practical and theoretical parts of this work.

\section{LITERATURE CITED}

Azam, F., Fenchel, T., Field, J. G., Gray, J. S., Meyer-Reil, L. A., Thingstad, F (1983). The ecological role of watercolumn microbes in the sea. Mar Ecol. Prog. Ser. 10: $257-263$

Andersen, O. K., Goldman, J. C., Caron, D. A., Dennett, M. R (1986). Nutrient cycling in a microflagellate food chain: III. Phosphorus dynamics. Mar. Ecol. Prog. Ser. 31 47-55

Bratbak, G., Thungstad, T. F. (1985). Phytoplankton-bacteria interactions: an apparent paradox? Analysıs of a model system with both competition and commensalism. Mar Ecol. Prog. Ser. 25: 23-30

Brown, E. J., Button, D. K., Lang, D. S. (1981). Competition between heterotrophic and autotrophic microplankton for dissolved nutrients. Microb. Ecol. 7: 199-206

Caron, D. A., Goldman, J. C., Andersen, O. K, Dennett, M. R. (1985). Nutrient cycling in a microflagellate food chain: 
II. Population dynamics and carbon cycling. Mar. Ecal. Prog. Ser. 24: 243-254

Currie, D. J., Kalff, J. (1984). Can bacteria outcompete phytoplankton for phosphorus? A chemostat test. Microb. Ecol. 10: $205-216$

Droop, M. R. (1968). Vitamin $B_{12}$ and marine ecology. IV The kinetics of uptake, growth and inhibition in Monochrysis lutheri. J. mar. biol. Ass. U.K. 48: 689-733

Eppley, R. W., Holmes, R. W., Strickland, J. D. H. (1967) Sinking rates of marine phytoplankton measured with a fluorometer. J. exp. mar. Biol. Ecol. 1: 191-208

Estep, K., Davis, P. G., Keller, M. D., Sieburth, J. McN. (1986). How important are oceanic algal nanoflagellates in bacterivory? Limnol. Oceanogr. 31:646-650

Fenchel, T (1982). Ecology of heterotrophic microflagellates. IV. Quantitative occurrence and importance as bacterial consumers. Mar. Ecol. Prog. Ser. 9: 35-42

de Freitas, M. J., Fredrickson, A. G. (1978). Inhibition as a factor in the maintenance of the diversity of microbial ecosystems. J. gen. Microbiol. 106: 307-320

van Gemerden, H. (1974). Coexistence of organisms competing for the same substrate: An example among the purple sulfur bacteria. Microb. Ecol. 1: 104-119

Goldman, J. C., Caron, D. A. (1985). Experimental studies on an omnivorous microflagellate: Implications for grazing and nutrient regeneration in the marine food chain. Deep Sea Res. 8: 899-915

Goldman, J. C., Caron, D. A., Andersen, O. K, Dennett, M. R. (1985). Nutrient cycling in a microflagellate food chain: I. Nitrogen dynamics. Mar. Ecol. Prog. Ser. 24: 231-242

Gottschal, J. C., de Vries, S., Kuenen, J. G. (1979). Competition between the facultatively chemolithotroph Thiobacillus A2, an obligately chemolithotrophic Thiobacillus and a heterotrophic spirillum for inorganic and organic nutrients. Arch. Microbiol. 121: 241-249

Gottschal, J. C., Thingstad, T. F. (1982). Mathematical description of competition between two and three bacterial species under dual substrate limitation in the chemostat: A comparison with experimental data. Biotechnol. Bioeng. 24: $1403-1418$

Grasshoff, K., Ehrhardt, M., Kremling, K. (ed.) (1983). Methods of seawater analysis. Verlag Chemie, Weinheim

Güde, H. (1985). Influence of phagotrophic processes on the regeneration of nutrients in two-stage continuous systems. Microb. Ecol. 11. 193-204

Guillard, R. R. L., Ryther, J. H. (1962). Studies of marine planktonic diatoms. I. Cyclotella nana Hustedt, and Detonula confervacea. (Cleve) Gran. Can. J. Microbiol. 8: $229-239$

Harder, W., Veldkamp, H. (1971). Competition of marine psychrophilic bacteria at low temperatures. Antonie van Leeuwenhoek 37: 51-63

Jost, J. L., Drake, J. F., Fredrickson, A. G., Tsuchiya, H. M. (1973a). Interactions between Tetrahymena pyriformis, Escherichia coli, Azotobacter vinelandii, and glucose in a minimal medium. J. Bacteriol. 113: 834-840

Jost, J. L., Drake, J. F., Tsuchiya, H. M., Fredrickson, A. G. (1973b). Microbial food chains and food webs. J. theor Biol. 41: 461-484

Kuenen, J. G., Boonstra, J., Schröder, H. G. J., Veldkamp, H. (1977). Competition for inorganic substrates among chemoorganotrophic and chemolithotrophic bacteria. Microb. Ecol. 3: 119-130

Odum, E. P. (1971). Fundamentals of ecology. Saunders, Philadelphia, p. 106

Parker, R. R., Sibert, J., Brown, T. J. (1975). Inhibition of primary productivity through heterotrophic competition for nitrate in a stratified estuary. J. Fish. Res. Bd Can. 32: $72-77$

Parsons, T. R., Albright, L. J., Whitney, F., Wong, C. S., Williams, P. J. LeB. (1981). The effect of glucose on the productivity of seawater: An experimental approach using controlled aquatic ecosystems. Mar, environ. Res. 4: 229-242

Pirt, S. J. (1982). Maintenance energy: A general model for energy-limited and energy-sufficient growth. Arch. Microbiol. 133: 300-302

Porter, K. G., Sherr, E. B., Sherr, B. F., Pace, M., Sanders, R. W. (1985). Protozoa in planktonic food webs. J. Protozool. 32: 409-415

Rhee, G. Y. (1972). Competition between an alga and an aquatic bacterium for phosphate. Limnol. Oceanogr. 17: $505-514$

Sakshaug, E., Olsen, Y. (1986). Nutrient status of phytoplankton blooms in Norwegian waters and algal strategies for nutrient competition. Can. J. Fish. Aquat. Sci. 43: 389-396

Sommer, U. (1984). The paradox of the plankton: Fluctuations of phosphorus availability maintain diversity of phytoplankton in flow-through cultures. Limnol. Oceanogr. 29: 633-636

Thingstad. T F. (1987). Utilization of N, P, and organic $C$ by heterotrophic bacteria. I. Outline of a chemostat theory with a consistent concept of 'maintenance' metabolism. Mar. Ecol. Prog. Ser. 35: 99-109

Thingstad, T. F., Pengerud, B. (1985). Fate and effect of allochthonous organic material in aquatic microbial ecosystems. An analysis based on chemostat theory. Mar. Ecol. Prog. Ser. 21: 47-62

Tilman, D., Kilham, S. S., Kilham, P. (1982). Phytoplankton community ecology: The role of limiting nutrients. Ann. Rev. Ecol. Syst. 13: 349-372 